\title{
A study of the impact of ergonomically designed workplaces on employee productivity
}

\author{
Leber, M. ${ }^{a}{ }^{*}$, Bastič, M. ${ }^{b}$, Moody, L. ${ }^{c}$, Schmidt Krajnc, M. ${ }^{d}$ \\ a University of Maribor, Faculty of Mechanical Engineering, Maribor, Slovenia \\ ${ }^{b}$ University of Maribor, Faculty of Economics and Business, Maribor, Slovenia

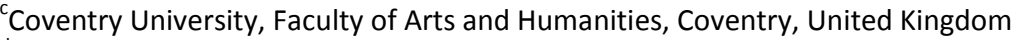 \\ dUniversity of Maribor, Faculty of Education, Maribor, Slovenia
}

\begin{abstract}
A B S T R A C T
Ergonomics principles help designing the workplace in a way that makes work more efficient and safer. Employee satisfaction increasingly affects the productivity of a process, which also includes disabled people and represents an important source of human resources. In the framework of the EU-project ERGO WORK a survey-based research was conducted to measure the satisfaction of people with disabilities (PWD) in their workplace and asses how their satisfaction was perceived by employers in UK, Poland and Slovenia. Three hundred and three respondents were involved in the survey. Results show that PWD place a great emphasis on the satisfaction in the workplace. PWD in Slovenia are more satisfied than PWD in Poland, whereas the employers' perception of the satisfaction of PWD and other employees in Poland, Slovenia and UK does not vary. A general adaptation of the workplace significantly and positively influences the satisfaction of persons with disability and that the adaptation of the workplace to the needs of PWD is better if employers have access to knowledge, special equipment and financial resources.
\end{abstract}

\section{ARTICLE INFO}

Keywords:

Productivity;

Satisfaction;

People with disabilities;

Workplace ergonomics

*Corresponding author:

marjan.leber@um.si

(Leber, M.)

Article history:

Received 13 March 2017

Revised 17 January 2018

Accepted 15 February 2018

\section{References}

[1] Kiełbasiński, A. (2014). Dlaczego umowy śmieciowe są złe. Pięć grzechów głównych według "Wyborczej”, from http://wyborcza.pl/1,75478,15262523,Dlaczego umowy smieciowe sa zle Piec grzechow glownych.html, acessed January 7, 2016.

[2] Bojarski, L. (2013). Poland - Country report non-discrimination 2013, European network of legal experts in gender and non-discrimination, from https://www.equalitylaw.eu/country/poland, accessed January 7, 2016.

[3] Moody, L., Saunders, J., Leber, M., Wójcik-Augustyniak, M., Szajczyk, M., Rebernik, N. (2017). An exploratory study of barriers to inclusion in the European workplace, Disability and Rehabilitation, Vol. 39, No. 20, 2047 2054, doi: $10.1080 / 09638288.2016 .1217072$.

[4] Papworth Trust. Disability in the United Kingdom 2014, Facts and Figures, from $\underline{\text { http://www.papworthtrust. }}$ org.uk, accessed January 7, 2015.

[5] Hoffmeister, K., Gibbons, A., Schwatka, N., Rosecrance, J. (2015). Ergonomics climate assessment: A measure of operational performance and employee well-being, Applied Ergonomics, Vol. 50, 160-169, doi: 10.1016/i.apergo. 2015.03.011.

[6] Wickens, C.D., Lee, J.D., Liu, Y., Gordon-Becker, S.E. (2004). An Introduction to Human Factors Engineering, 2nd edition, Pearson Prentice Hall, Upper Saddle River, New Jersey, USA.

[7] Sanders, M.S., McCormick, E.J. (1993). Human Factors in Engineering and Design, 7th edition, McGraw-Hill Education, New York, USA.

[8] McAtamney, L., Corlett, E.N. (1992). Ergonomic workplace assessment in a health care context, Ergonomics, Vol. 35, No. 9, 965-978, doi: 10.1080/00140139208967376. 
[9] Feyen, R., Liu, Y., Chaffin, D., Jimmerson, G., Joseph, B. (2000). Computer-aided ergonomics: A case study of incorporating ergonomics analyses into workplace design, Applied Ergonomics, Vol. 31, No. 3, 291-300, doi: 10.1016/S0003-6870(99)00053-8.

[10] Harih, G., Borovinsek, M., Ren, Z., Dolsak, B. (2015). Optimal products' hand-handle interface parameter identification, International Journal of Simulation Modelling, Vol. 14, No. 3, 404-415, doi: 10.2507/IJSIMM14(3)3.285.

[11] Ergo Work. Ergo work recommendations for the system and policy makers, from $\underline{\text { ttp://www.ergo-work.eu/site/ }}$ english site/link en.html\#den, accessed January 7, 2016.

[12] Kopelman, R.E., Brief, A.P., Guzzo, R.A. (1990). The role of climate and culture in productivity, In: Schneider, B. (Ed.), Organizational climate and culture, Jossey-Bass, San Francisco, USA, 282-318.

[13] Mihanović, V. (2011). Disability in the context of a social model, Hrvatska revija za rehabilitacijska istraživanja, Vol. 47, No. 1, 72-86.

[14] Alborno, N., Gaad, E. (2012). Employment of young adults with disabilities in Dubai - A case study, Journal of Policy and Practice in Intellectual Disabilities, Vol. 9, No. 2, 103-111, doi: 10.1111/j.1741-1130.2012.00341.x.

[15] Hair Jr., J.F., Black, W.C., Babin, B.J., Anderson, R.E. (2010). Multivariate data analysis: A global perspective, 7th edition, Pearson Education, Upper Saddle River, New Jersey, USA.

[16] Andrews, A., Rose, J.L. (2010). A preliminary investigation of factors affecting employment motivation in people with intellectual disabilities, Journal of Policy and Practice in Intellectual Disabilities, Vol. 7, No. 4, 239-244, doi: 10.1111/j.1741-1130.2010.00272.x.

[17] Kogi, K. (2012). Practical ways to facilitate ergonomics improvements in occupational health practice, Human Factors: The Journal of the Human Factors and Ergonomics Society, Vol. 54, No. 6, 890-900, doi: 10.1177/0018720 812456204.

[18] Karwowski, W. (2012). A review of human factors challenges of complex adaptive systems: Discovering and understanding chaos in human performance, Human Factors: The Journal of the Human Factors and Ergonomics Society, Vol. 54, No. 6, 983-995, doi: 10.1177/0018720812467459.

[19] Menozzi, M., Von Buol, A., Waldmann, H., Kundig, S., Krueger, H., Spieler, W. (1999). Training in ergonomics at VDU workplaces, Ergonomics, Vol. 42, No. 6, 835-845, doi: 10.1080/001401399185324.

[20] Kleiner, B.M. (2008). Macroergonomics: Work system analysis and design, Human Factors: The Journal of the Human Factors and Ergonomics Society, Vol. 50, No. 3, 461-467, doi: 10.1518/001872008X288501. 